\title{
Choice of antibiotics in late neonatal sepsis in the extremely low birth weight infant
}

\author{
Tara R Allen BSc, Orlando P da Silva MD MSc FRCPC
}

TR Allen, OP da Silva. Choice of antibiotics in late neonatal sepsis in the extremely low birth weight infant. Can J Infect Dis $2003 ; 14(1): 28-31$.

OBJECTIVE: To review the choice of antibiotics in treating suspected late neonatal sepsis in infants weighing $1000 \mathrm{~g}$ or less in a neonatal intensive care unit.

METHODS: Retrospective review of medical records.

RESULTS: Ninety-six infants weighing $1000 \mathrm{~g}$ or less were admitted to the neonatal intensive care unit during the study period. Sixty-two infants survived beyond four days of life and had at least one sepsis workup done to exclude late neonatal infection. Of the 62 study patients, $42(68 \%)$ were started on ampicillin and netilmicin (A/N) and $20(32 \%)$ were started on vancomycin and ceftizoxime (V/C) as the antibiotics of choice, pending culture results. Of the patients started on $\mathrm{A} / \mathrm{N}, 17$ of $42 \mathrm{had}$ a positive blood culture compared with 11 of 20 on $\mathrm{V} / \mathrm{C}(40 \%$ versus $55 \%, \mathrm{P}=0.40)$. The mean $( \pm \mathrm{SD})$ birth weight of infants started on $\mathrm{A} / \mathrm{N}$ was $793 \pm 133 \mathrm{~g}$ compared with a mean of $728 \pm 153 \mathrm{~g}$ in the group that received V/C $(\mathrm{P}=0.09)$. Seven patients died in the $\mathrm{A} / \mathrm{N}$ group compared with three in the $\mathrm{V} / \mathrm{C}$ group ( $16.7 \%$ versus $15 \%, P=0.84)$. In addition to the sepsis episode studied, before they were discharged from hospital, 21 of $42(50 \%)$ infants in the $\mathrm{A} / \mathrm{N}$ group had further workups for suspected sepsis, compared with 16 of $20(80 \%)(\mathrm{P}=0.048)$ infants initially given V/C.

CONCLUSIONS: Ampicillin and netilmicin is a safe antibiotic combination for neonates suspected of late sepsis. This, in turn, may be important in reducing vancomycin overuse and the potential for bacterial resistance to this antimicrobial agent.

Key Words: Antibiotics; Neonate; Sepsis

$\mathrm{B}$ acterial resistance to available antibiotics is a global problem with severe consequences for public health. The overuse of antimicrobials is thought to be responsible for the induction of bacterial resistance $(1,2)$. Because of the high risk of nosocomial infection and the associated serious morbidity in the extremely premature infant, these patients are frequently exposed to empirical broad-spectrum antibiotics until the cultures of blood, urine and spinal fluid become available from the laboratory, which contributes to the problem of overuse of antimicrobials (3).

Coagulase negative staphylococci (CoNS) have become some of the most prevalent organisms implicated in late sepsis (occurring after more than four days of life) in a neonatal intensive care unit (NICU) (4-6). This organism is usually resistant to a number of commonly used antibiotics; however, it remains sensitive to vancomycin $(4,7)$. For this reason, neonatologists usually add this antibiotic to the empirical com-
Le choix d'antibiotiques en cas de septicémie néonatale tardive chez le nourrisson de très petit poids de naissance

OBJECTIF : Évaluer le choix d'antibiotiques dans le traitement de la septicémie néonatale tardive présumée chez les nourrissons de 1000 g ou moins d'une unité de soins intensifs néonatals.

MÉTHODOLOGIE : Examen rétrospectif des dossiers médicaux

RÉSULTATS : Quatre-vingt-seize nourrissons de $1000 \mathrm{~g}$ ou moins ont été admis à l'unité de soins intensifs néonatals pendant la période de l'étude. Soixante-deux nourrissons ont vécu plus de quatre jours et ont subi au moins un bilan de septicémie afin d'exclure la présence d'infection néonatale tardive. Parmi ces 62 patients à l'étude, 42 (68 \%) ont d'abord reçu de l'ampicilline et de la nétilmicine (A/N) et 20 (32\%), de la vancomycine et de la ceftizoxime $(\mathrm{V} / \mathrm{C})$ comme antibiotiques de choix, dans l'attente des résultats des cultures. Parmi les patients prenant de l'A/N, 17 des 42 présentaient une hémoculture positive par rapport à 11 des 20 prenant de la $\mathrm{V} / \mathrm{C}(40 \%$ par rapport à $55 \%, \mathrm{P}=0,40)$. Le poids moyen $( \pm E ́ T)$ à la naissance des nourrissons ayant pris de l'A/N était de $793 \pm 133 \mathrm{~g}$, par rapport à une moyenne de $728 \pm 153 \mathrm{~g}$ de ceux prenant de la $\mathrm{V} / \mathrm{C}(\mathrm{P}=0,9)$. Sept patients sont décédés dans le groupe prenant de l'A/N, par rapport à trois dans celui prenant de la $\mathrm{V} / \mathrm{C}(16,7 \%$ par rapport à $15 \%, \mathrm{P}=0,84)$. En plus de l'épisode de septicémie étudié, avant leur congé de l'hôpital, 21 des 42 (50 \%) nourrissons du groupe prenant de l'A/N ont subi des bilans supplémentaires de septicémie présumée, par rapport à 16 des $20(80 \%)(\mathrm{P}=0,048)$ des nourrissons ayant d'abord reçu de la V/C. CONCLUSIONS : L'ampicilline et la nétilmicine représentent une association d'antibiotiques sûre pour les nouveau-nés présentant une septicémie tardive présumée. Cette constatation pourrait être importante afin de réduire la surutilisation de vancomycine et le potentiel de bactériorésistance à cet antimicrobien.

St Joseph's Health Care London, Department of Paediatrics, Child Health Research Institute, University of Western Ontario, London, Ontario Correspondence and reprints: Dr Orlando da Silva, St Joseph's Health Care London, London, Ontario N6A 4V2. Telephone 519-646-6100 ext 65291,fax 519-646-6123, e-mail odasilva@uwo.ca

Received for publication October 23, 2001. Accepted February 19, 2002

bination when treating suspected late neonatal sepsis, pending the results of cultures.

Of all sepsis workups done in an NICU, only a small proportion of them will actually be proven sepsis with a positive culture of blood, spinal fluid or urine (8). This dilemma usually leads to the overuse of vancomycin, with its associated risk of inducing bacterial resistance. In an attempt to prevent the spread of vancomycin-resistant enterococci, the Centers for Disease Control and Prevention (CDC), Atlanta, Georgia has issued a statement recommending guidelines for the prudent use of vancomycin (9). Although CoNS is a very common organism that can cause sepsis in the premature infant, it is usually not as virulent as other organisms and it is rarely associated with mortality (5). Therefore, it is assumed to be safe for the neonatal patient to be started on broad-spectrum antibiotic coverage that does not include vancomycin until the culture results become available (5). If the cultures show growth of 
CoNS, a specific coverage with vancomycin may be instituted. We believe this approach would drastically reduce the use of vancomycin in an NICU. Over the past years, CoNS isolated from patients in the authors' centre have shown sensitivity to the aminoglicoside netilmicin. Clinicians have been encouraged to use the empirical combination of netilmicin and ampicillin when late neonatal sepsis is suspected. Once the cultures become available, a decision can be made concerning which antimicrobial agents to use to target the specific isolate. The present study was conducted to assess the safety of this recommendation.

\section{METHODS}

The medical records of all infants weighing $1000 \mathrm{~g}$ or less and admitted to the NICU at St Joseph's Health Care, London, Ontario between January 1, 1999 and June 30, 2000 were reviewed. This unit is a tertiary referral perinatal centre for the southwestern region of Ontario. Infants were included if they had a sepsis workup at more than four days of life to rule out late sepsis and were started on empirical antibiotics. According to unit guidelines for the empirical treatment of late neonatal sepsis, the clinicians had the option of starting either the combination of ampicillin and netilmicin $(\mathrm{A} / \mathrm{N})$ or vancomycin and the third generation cephalosporin ceftizoxime (V/C). Patients were excluded if they died before four days of age; received antibiotics within the first $24 \mathrm{~h}$ of life only and had no subsequent courses of antibiotics; were transferred to our unit after having received one or more courses of antibiotics at older than four days of life in another institution; and if the clinicians chose empirical antibiotics other than $\mathrm{V} / \mathrm{C}$ or $\mathrm{A} / \mathrm{N}$.

Detailed data were abstracted from the health records and stored in a computer program for later analysis. The decision to start either the combination of $\mathrm{V} / \mathrm{C}$ or $\mathrm{A} / \mathrm{N}$ was made at the discretion of the clinician caring for the infants. For the purpose of the analysis, the first nosocomial sepsis workup was examined (the first sepsis workup to rule out sepsis at older than four days of life).

Informed consent was not sought because the physicians' preference for the combination of antibiotics is the standard of care, and data were collected and analyzed anonymously. However, parents and guardians were informed of all antibiotic treatments.

\section{RESULTS}

During the study period, 96 infants weighing $1000 \mathrm{~g}$ or less were admitted to the NICU. Sixty-two patients were worked up for late neonatal sepsis and were included in the study. Thirty-four infants were excluded (Figure 1). The clinicians opted to start 42 infants on $\mathrm{A} / \mathrm{N}$ and 20 infants on $\mathrm{V} / \mathrm{C}$ (Figure 1). The patients' characteristics are shown in Table 1 . In the $\mathrm{A} / \mathrm{N}$ group there were more male infants than females $(\mathrm{P}=0.006)$. The mean postnatal age of the septic episode in infants in the $\mathrm{A} / \mathrm{N}$ group was $17.5 \pm 8.5$ days, compared with $11.9 \pm 5.8$ days in the $\mathrm{V} / \mathrm{C}$ group $(\mathrm{P}=0.01)$. There were no statistically significant differences in both groups in any of the other variables analyzed.

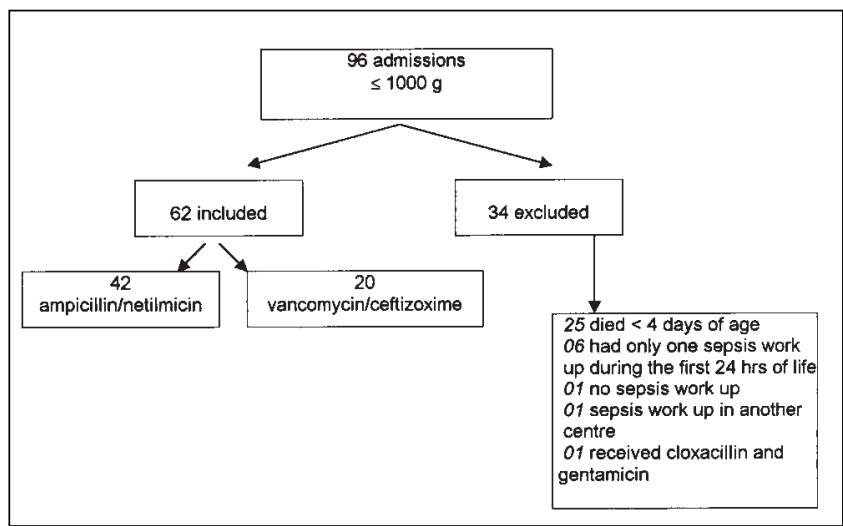

Figure 1) Flow diagram of study patients

\section{TABLE 1}

Characteristics of patients studied

\begin{tabular}{|c|c|c|c|}
\hline & $\begin{array}{l}\text { Neonates on ampicillin } \\
\text { and netilmicin }\end{array}$ & $\begin{array}{l}\text { Neonates on vancomycin } \\
\text { and ceftizoxime }\end{array}$ & $\mathbf{P}$ \\
\hline Number of neonates & 42 & 20 & - \\
\hline \multicolumn{4}{|l|}{ Sex } \\
\hline Male & 28 & 11 & - \\
\hline Female & $14(P=0.006)$ & 9 & \\
\hline Birth weight (g) & $794 \pm 133$ & $728 \pm 153$ & 0.09 \\
\hline Gestational age (weeks) & $25.9 \pm 1.4$ & $25.1 \pm 1.7$ & 0.06 \\
\hline Retinopathy of prematurity - any stage (\%) & $66.7(n=28)$ & $75(n=15)$ & 0.71 \\
\hline Retinopathy of prematurity - stages 3 to $5(\%)$ & $40.9(n=17)$ & $65(n=13)$ & 0.13 \\
\hline Intraventricular hemorrhage - any grade (\%) & $54.8(n=23)$ & $55(n=11)$ & 0.14 \\
\hline Intraventricular hemorrhage - grades 3 or $4(\%)$ & $14.3(n=6)$ & $25(n=5)$ & 0.50 \\
\hline Necrotizing enterocolitis - stage 2 or $3(\%)$ & $7.14(n=3)$ & $5(n=1)$ & 0.08 \\
\hline Days in hospital $67.1 \pm 28.3$ & $77.5 \pm 32.7$ & 0.20 & \\
\hline Mortality to discharge (\%) & $16.7(n=7)$ & $15(n=3)$ & 0.84 \\
\hline Age at septic episode (days) & $17.5 \pm 8.5$ & $11.9 \pm 5.8$ & 0.01 \\
\hline Per cent with central line & $69.1(n=29)$ & $75(n=15)$ & 0.86 \\
\hline \multicolumn{4}{|l|}{ Bronchopulmonary dysplasia } \\
\hline 28 days $(\%)$ & $62(n=26)$ & $85(n=17)$ & 0.12 \\
\hline 36 weeks (\%) & $40(n=17)$ & $45(n=9)$ & 0.92 \\
\hline
\end{tabular}


TABLE 2

Sepsis episodes studied

\begin{tabular}{lcc}
\hline & $\begin{array}{c}\text { Neonates on } \\
\text { ampicillin } \\
\text { and netilmicin } \\
(\mathbf{n}=\mathbf{4 2})\end{array}$ & $\begin{array}{c}\text { Neonates on } \\
\text { vancomycin } \\
\text { and ceftizoxime } \\
(\mathbf{n}=\mathbf{2 0})\end{array}$ \\
\hline $\begin{array}{c}\text { Number with positive } \\
\text { cultures (Blood) } \\
\text { Organism isolated }\end{array}$ & $17(40 \%)$ & $11(55 \%)$ \\
& $\begin{array}{c}\text { CoNS } n=12 \\
\text { Candida } n=2 \\
\text { Escherichia coli } n=2\end{array}$ & CoNS $n=11$ \\
$\begin{array}{c}\text { Per cent abnormal l/T ratio } \\
(I / T \geq 0.20)\end{array}$ & $31 \%(n=13)$ & $20 \%(n=4)$ \\
$\begin{array}{c}\text { Abnormal WBC count } \\
\text { (WBC }<7 \text { or }>30)\end{array}$ & $11.9 \%(n=5)$ & $10 \%(n=2)$ \\
$\begin{array}{c}\text { Per cent with } \geq 3 \\
\text { clinical signs }\end{array}$ & $61.9 \%(n=26)$ & $20 \%(n=6)$ \\
\hline
\end{tabular}

*Increased number of apneas and bradycardias, temperature instability, poor perfusion, feeding intolerance, abdominal distension, bile aspirate, frank blood in the stools, intramural gas on abdominal $x$-ray, central venous catheter. CoNS Coagulase negative staphylococci; I/T Immature to total neutrophil ratio; WBC White blood cell count

In the $\mathrm{A} / \mathrm{N}$ group, 17 infants had a positive blood culture, compared with 11 infants in the $\mathrm{V} / \mathrm{C}$ group (40\% versus $55 \%$, $\mathrm{P}=0.40$ ). Urine and spinal fluid cultures were negative in both groups. The organisms isolated are shown in Table 2.

All species of CoNS isolated during the study period were sensitive to netilmicin. In patients from the $\mathrm{A} / \mathrm{N}$ group whose blood cultures were positive for CoNS, the ampicillin was stopped in all 12 patients once culture results became available. In seven of the 12 (58\%) patients, the clinicians continued treatment with netilmicin as single therapy, and in five of the $12(42 \%)$ patients, treatment was changed to vancomycin monotherapy. In the patients started on $\mathrm{V} / \mathrm{C}$ whose cultures turned out to be positive for CoNS, treatment was completed with vancomycin single therapy in all patients, except in two infants who had a concomitant endotracheal aspirate positive for Gram-negative bacilli. These two patients were given a full course of the combination $\mathrm{V} / \mathrm{C}$. The duration of antibiotic therapy in both groups ranged from seven to 10 days according to the decision made by the attending physician. In all 34 patients in both groups whose blood cultures failed to grow any organisms, the antibiotic combination was discontinued within a variable period of two to five days, depending on when culture results were made available and the severity of their clinical conditions at the start of antibiotics.

The peripheral leukocyte count and ratios during the sepsis episodes were similar in both groups; however, infants given $\mathrm{A} / \mathrm{N}$ had more clinical signs of sepsis compared with those in the $\mathrm{V} / \mathrm{C}$ group (61.9\% versus $20 \%, \mathrm{P}=0.005$ ) as shown in Table 2. All infants with CoNS positive blood cultures in both groups had a percutaneously inserted central venous line in situ. After the initiation of antibiotics, all patients improved clinically with the line in place; only one patient had his line removed because of slow clinical response to antibiotics, and a blood sample taken from the line also grew CoNS.

Before they were discharged from hospital, 21 of the 42 (50\%) infants in the $\mathrm{A} / \mathrm{N}$ group had further workups for sus-
TABLE 3

Characteristics of patients who died

\begin{tabular}{|c|c|c|c|c|}
\hline Patient & $\begin{array}{c}\text { GA } \\
\text { (weeks) }\end{array}$ & $\begin{array}{c}\text { BWT } \\
\text { (grams) }\end{array}$ & $\begin{array}{l}\text { Age at death } \\
\text { (days) }\end{array}$ & Cause of death \\
\hline \multicolumn{5}{|c|}{ Vancomycin/ceftizoxime group } \\
\hline 1 & 24 & 615 & 41 & Multiorgan failure \\
\hline 2 & 24 & 773 & 7 & Necrotizing enterocolitis \\
\hline 3 & 24 & 461 & 32 & Candida sepsis \\
\hline \multicolumn{5}{|c|}{ Ampicillin/netilmicin group } \\
\hline 1 & 23 & 600 & 15 & Respiratory failure \\
\hline 2 & 27 & 735 & 42 & $\begin{array}{l}\text { Severe BPD, } \\
\text { respiratory failure }\end{array}$ \\
\hline 3 & 25 & 810 & 72 & Necrotizing enterocolitis \\
\hline 4 & 24 & 692 & 11 & $\begin{array}{l}\text { Respiratory failure } \\
\text { grade } 4 \mathrm{IVH}\end{array}$ \\
\hline 5 & 27 & 435 & 30 & Respiratory failure \\
\hline 6 & 25 & 740 & 35 & $\begin{array}{l}\text { Intracranial hemorrhage } \\
\text { or hydrocephalus }\end{array}$ \\
\hline 7 & 25 & 650 & 29 & Multiorgan failure \\
\hline
\end{tabular}

BPD Bronchopulmonary dysplasia; BWT Birth weight; GA Gestational age, IVH Intraventricular hemorrhage

pected sepsis, compared with 16 of the $20(80 \%)(\mathrm{P}=0.048)$ infants initially given $\mathrm{V} / \mathrm{C}$, in addition to the sepsis episode studied.

A total of 10 patients died before discharge from hospital. Seven died in the $\mathrm{A} / \mathrm{N}$ group compared with three in the $\mathrm{V} / \mathrm{C}$ group $(16.7 \%$ versus $15 \%, \mathrm{P}=0.84)$. None of the deaths was due to bacteria that were resistant to the antibiotics chosen. One extremely premature infant receiving $\mathrm{V} / \mathrm{C}$ died of overwhelming Candida sepsis. Details of the patients who died are shown in Table 3.

All patients were started on ampicillin and gentamicin empirically within the first $24 \mathrm{~h}$ of life to rule out perinatally acquired early neonatal sepsis, until the results of cultures became available.

\section{DISCUSSION}

The decision of which antibiotic combination to use was made at the discretion of the attending neonatologist looking after the infant at the time of the sepsis workup. Clinicians chose A/N more often than V/C. Once the cultures became available, clinicians had the option of choosing single antibiotic coverage, therefore limiting the use of vancomycin to those cases of proven CoNS sepsis. In the majority of cases in the $\mathrm{A} / \mathrm{N}$ group, the infants showed excellent clinical response and netilmicin was maintained as the antibiotic of choice. We believe this clinical response was because the CoNS isolated were sensitive to netilmicin. Contamination of the blood culture is a possible but unlikely explanation, because other investigators from this centre have previously shown that the majority of CoNS isolated from our NICU were true pathogens (8).

There were no deaths associated with this approach. Except for one infant who died of a fungal infection, all other deaths were associated with complications of extreme prematurity. No infant died of bacterial sepsis. When compared with the V/C group, the infants given $\mathrm{A} / \mathrm{N}$ had no increase in neonatal morbidity. The infants in the $\mathrm{A} / \mathrm{N}$ group had the sepsis workup at 
a later age than those in the $\mathrm{V} / \mathrm{C}$ group. We could not find an explanation for this finding, given that the infants were of similar birth weight and gestational age and that they received similar care during their hospital stay. Because this was not a randomized trial and data were collected retrospectively, it is possible that physicians' preferences played a role in these findings. If clinical deterioration happened earlier in the hospital course, a clinician faced with a sick infant suspected of nosocomial infection may have felt inclined to be more aggressive with antibiotic coverage at a lower gestational age. It is our hypothesis that this happened in the present study, given that although the differences in gestational age and birthweight in both groups were not statistically significant, there was a trend toward younger and smaller infants in the $\mathrm{V} / \mathrm{C}$ group (Table 1 ). However, it is unlikely that this difference imposed any bias on the results in view of the similar outcomes.

Since the CDC released its recommendations, a reduction in the empirical use of vancomycin has been reported by various centres $(5-7,10)$. In a recent study, Karlowitz et al (5) examined 825 episodes of late onset sepsis occurring in 536 infants over a 10 -year period. The authors found a very low frequency of fulminant sepsis caused by CoNS during the entire study period. This frequency did not increase during the latter part of the study, when the clinicians changed empirical antibiotic therapy for late onset sepsis from vancomycin and cefotaxime to oxacillin and gentamicin (5). Other investigators have shown similar results, with no increase in morbidity and mortality associated with the decrease in the use of empirical vancomycin (10).

Another advantage of our approach to antibiotics usage was also the reduction in the use of third generation cephalosporins. This class of antibiotics has been shown to select strains of Enterobacter species and Serratia species, which contain genetic material coding for beta-lactamase production

\section{REFERENCES}

1. Goldmann DA, Uskins WC. Control of nosocomial antimicrobialresistant bacteria: A strategic priority for hospitals worldwide. Clin Infec Dis 1997;24(Suppl 1):139-45.

2. Edmond MB, Ober JF, Weinbaum DL. Vancomycin-resistant Enterococcus faecium bacteria: Risk factors for infection. Clin Infect Dis 1995;20:1126-33.

3. Stoll BJ, Gordon T, Korones SB, et al. Late-onset sepsis in very low birth weight neonates: A report from the National Institute of Child Health and Human Development Neonatal Research Network. J Pediatr 1996;129:63-71.

4. Cordero L, Sananes M, Ayers LW. Bloodstream infections in a neonatal intensive-care unit: 12 years' experience with an antibiotic control program. Infect Control Hosp Epidemiol 1999;20:242-6.

5. Karlowicz MG, Buescher ES, Surka AE. Fulminant late-onset sepsis in a neonatal intensive care unit, 1988-1997, and the impact of avoiding empiric vancomycin therapy. Pediatrics 2000;106:1387-90.

6. Isaacs D. Rationing antibiotic use in neonatal units. Arch Dis Child Fetal Neonatal Ed 2000;82:F1-2.

7. Sinowitz RL, Keyserling H, Walker TJ, Holland J, Jarvis WR. Epidemiology of vancomycin usage in a newborn intensive care unit. Pediatr Infect Dis J 1997;16:485-9.

8. Hammerberg O, Bialkowska-Hobranska H, Gregson D, Potters H, Gopaul D, Reid D. Comparison of blood cultures with corresponding venipuncture site cultures of specimens from hospitalised premature neonates. J Pediatr 1992;120:120-4

9. Centers for Disease Control and Prevention. Preventing the spread of vancomycin resistance - a report from the Hospital Infection Control Practice Advisory Committee prepared by the Subcommittee on Prevention and Control of Antimicrobial- and, therefore, bacterial resistance (11-16). In a recent study, de Man et al (17) reported a nonblinded crossover trial examining two different antibiotic regimes in two neonatal units. The infants were randomly assigned according to unit admission to receive either penicillin and tobramycin or ampicillin and cefotaxime for early sepsis evaluation. The antibiotic combination was switched after six months. The authors found an 18-fold increase in the rate of colonization with resistant strains of Gram-negative organisms in the units when the amoxicillin and cefotaxime regimen was used compared with when the penicillin and tobramycin regimen was used. Although the goal of the present study was not to investigate bacterial resistance, these findings reinforce our policy of judicious use of antibiotics in a neonatal unit.

Despite the limitations of our study, it has become evident that the prudent and judicious use of vancomycin as an empirical antibiotic had no detrimental impact on neonatal morbidity and mortality.

\section{CONCLUSIONS}

A/N is a safe antibiotic combination for neonates suspected of late sepsis. This in turn may be important in reducing the overuse and potential for bacterial resistance to vancomycin. A large multicentre randomized trial of different antibiotic combinations in late neonatal sepsis is warranted to assess the true impact of a policy of vancomycin restriction on neonatal outcome and the risk of development of vancomycin-resistant organisms in a neonatal intensive care setting.

ACKNOWLEDGEMENTS: Ms Allen was supported by a grant from the summer career placement program, Province of Ontario, and matching funds from the Child Health Research Institute, Department of Paediatrics, University of Western Ontario.

Resistant Microorganisms in Hospitals. Federal Register 1994;59:22758-63.

10. Matrai-Kovalskis Y, Greenberg D, Shinwell ES, Fraser D, Dagan R. Positive blood cultures for Coagulase-negative staphylococci in neonates: Does highly selective vancomycin usage affect outcome? Infection 1998;26:85-92.

11. Bryan CS, John GF, Pai MS, Austin TL. Gentamicin vs cefotaxime for therapy of neonatal sepsis: Relationship to drug resistance. Am J Dis Child 1985;139:1086-9.

12. Spritzer R, Kamp HJ, Dzoljic G, Sauer PJ. Five years of cefotaxime use in a neonatal intensive care unit. Pediatr Infect Dis J 1990;9:92-6.

13. Haertl R, Bandlow G. Molecular typing of Enterobacter cloacae by pulsed-field gel electrophoresis restriction fragment. J Hosp Infect 1993;25:109-16.

14. Modi N, Damjonovic V, Cooke RW. Outbreak of cephalosporin resistant Enterobacter cloacae infection in a neonatal intensive care unit. Arch Dis Child 1987;62:148-51.

15. Verweij PE, Van Belkum A, Melchers WJ, Hoogkamp-Korstanje JA, Meis JF. Interrepeat fingerprinting of third-generation cephalosporinresistant Enterobacter cloacae isolated during an outbreak in a neonatal intensive care unit. Infect Control Hosp Epidemiol 1995;16:25-9.

16. Venezia RA, Scarano FJ, Preston KE, et al. Molecular epidemiology of an SHV-5 extended-spectrum beta-lactamase in enterobacteriaceae isolated from infants in a neonatal intensive care unit. Clin Infect Dis 1995;21:915-23.

17. de Man P, Verhoeven BAN, Verbrugh HA, Vos MC, den Anker JN. Antibiotic policy to prevent emergence of resistant bacilli. Lancet 2000;355:973-8. 


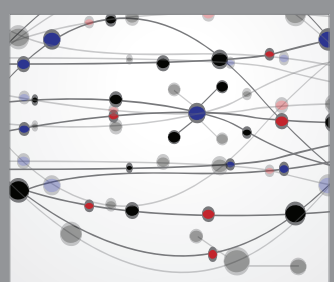

The Scientific World Journal
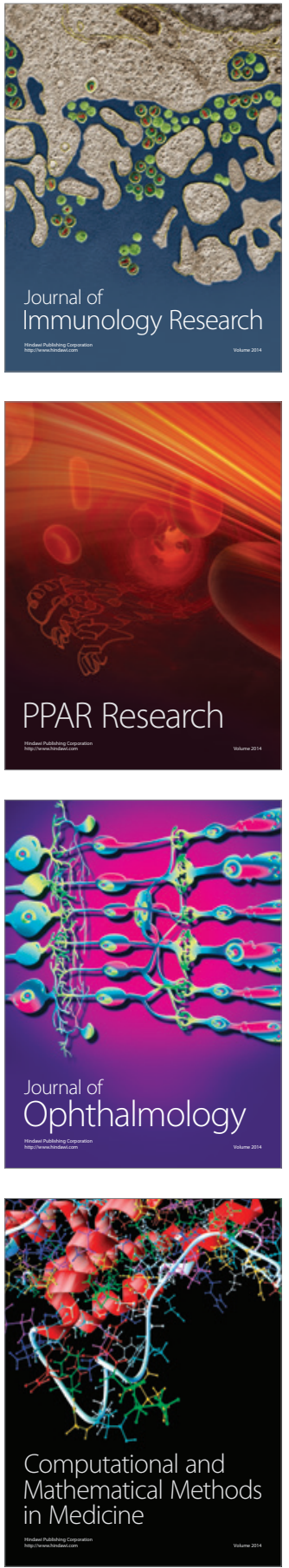

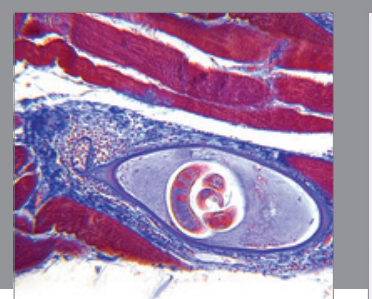

Gastroenterology Research and Practice

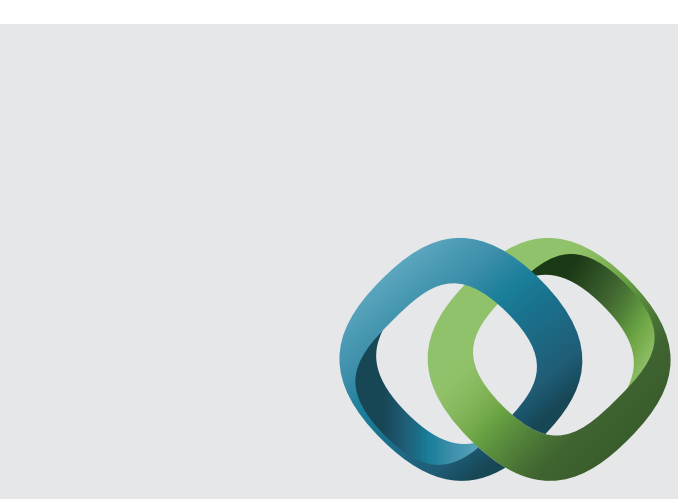

\section{Hindawi}

Submit your manuscripts at

http://www.hindawi.com
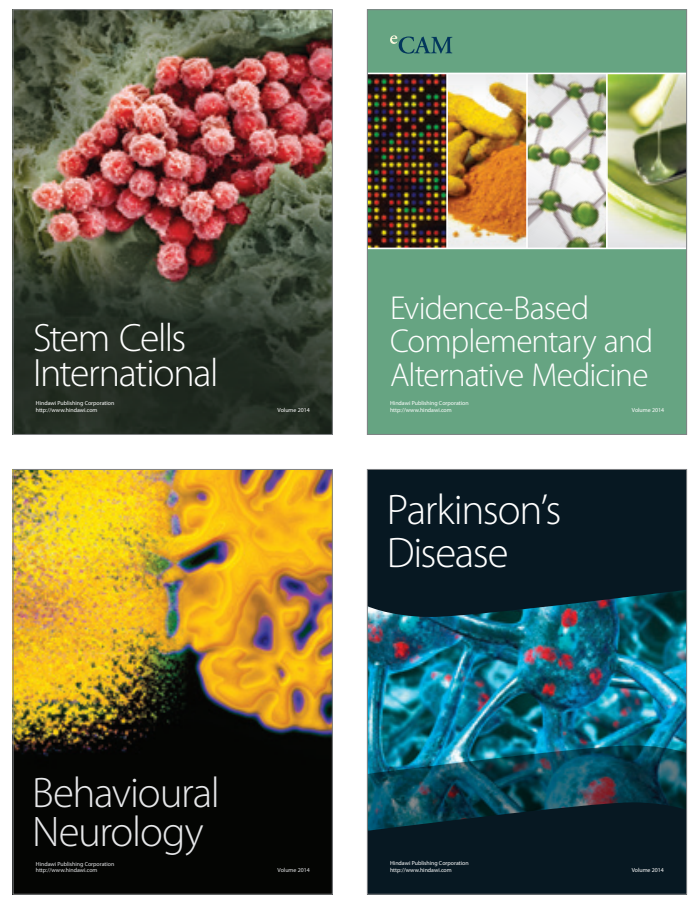
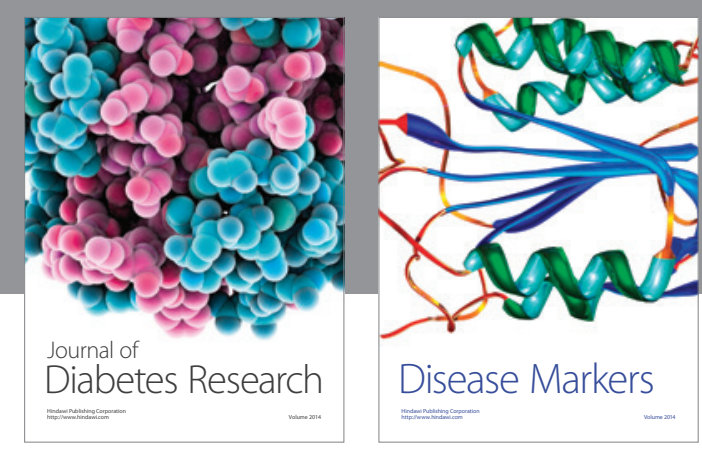

Disease Markers
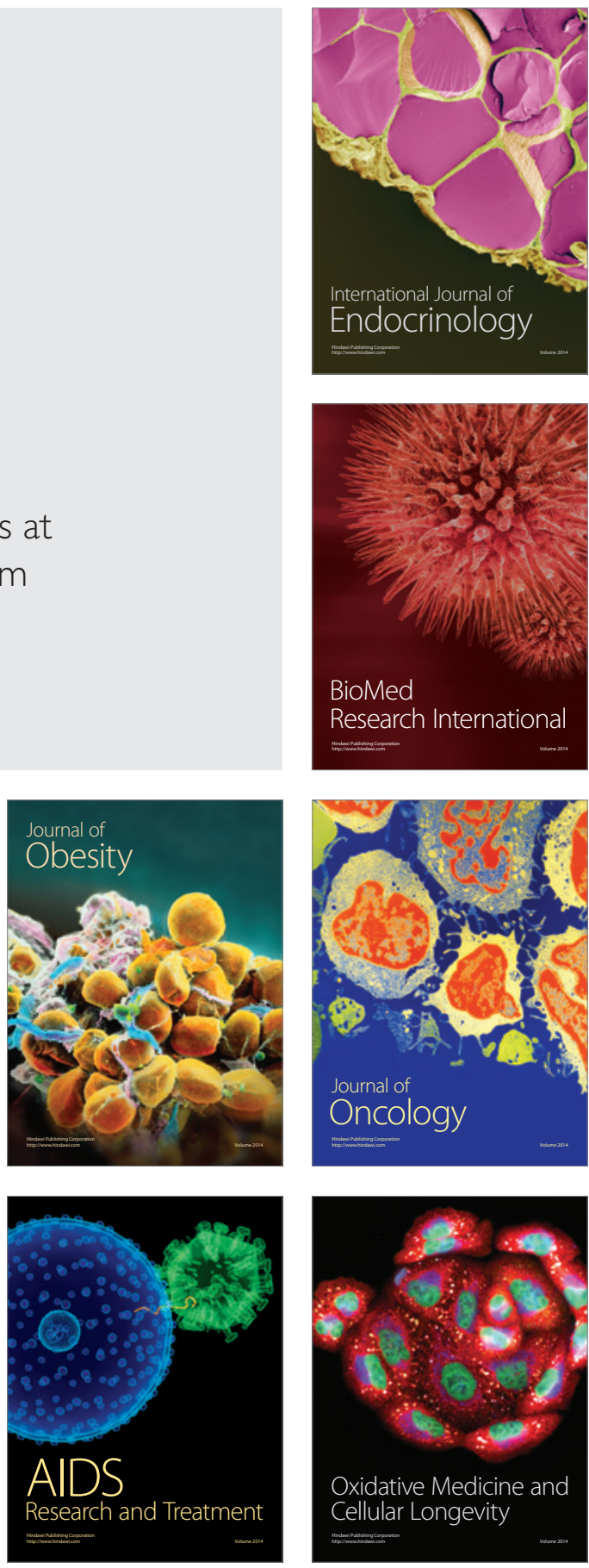